\title{
Histological and immunohistochemical evaluation of the dose- dependent effect of gold nanoparticles on the renal cortex of adult female albino rat
}

\section{Original Article}

\author{
Walaa M. Elwan', Ayah M. H. Ragab ${ }^{2}$ and Mohamed H. Ragab \\ ${ }^{1}$ Department of Histology, Faculty of Medicine, Tanta University, Tanta, Egypt \\ ${ }^{2}$ Reproductive Health and Family Planning Department, National Research Centre, Giza, \\ Egypt \\ ${ }^{3}$ Department of Anatomy, Faculty of Medicine, Tanta University, Egypt
}

\begin{abstract}
Introduction: Applications of gold nanoparticles (GNPs) in modern life lead to the release of GNPs into the environment, thus representing a potential hazard to human health.

Aim of the work: To evaluate the effect of GNPs on the renal cortex of adult female rats employing different histological and immunohistochemical techniques.

Materials and Methods: Thirty adult female albino rats were divided into three equal groups; Group I (Control), in groups II and group III, GNPs were administered daily as $40 \mu \mathrm{g} / \mathrm{kg}$ and $400 \mu \mathrm{g} / \mathrm{kg}$ for 14 days, respectively. Specimens were processed for light and electron microscopy, in addition to immunohistochemical staining for tumor necrosis factor-alpha (TNF- $\alpha$ ).

Results: GNPs-treated animals showed many hypercellular glomeruli. Most proximal convoluted tubules (PCTs) were severely distorted, their cells showed vacuolated cytoplasm and pyknotic nuclei. Many distal convoluted tubules (DCTs) showed exfoliated cells and some karyolytic nuclei. Some tubules were totally distorted. Dilated congested blood vessels together with extensive mononuclear cellular aggregations were observed. Ultrastructural examination revealed podocytes with small heterochromatic nuclei and interrupted processes with distortion and effacement. Many GNPs resided in the podocytic terminal processes. Some cells of PCTs showed irregular nuclei, variably sized and shaped mitochondria with loss of their basal orientation. Focal areas of rarefied cytoplasm and apical vacuoles were observed. Cells of DCTs showed irregular nuclei and numerous abnormally shaped mitochondria. Irregularly thickened basal lamina and GNPs were clearly observed in their cytoplasm. The immunohistochemical study showed a highly significant increase in TNF- $\alpha$ immunoreaction. Conclusion: GNPs cause dose-dependent structural changes in renal cortex with various degrees of inflammation.
\end{abstract}

Received: 19 December 2017, Accepted: 24 February 2018

Key Words: Electron microscopy, gold nanoparticles, renal cortex, TNF- $\alpha$.

Corresponding Author: Walaa M. Elwan, Department of Histology, Faculty of Medicine, Tanta University, Tanta, Egypt, Tel.: 00201002596677, E-mail: w.elwan@yahoo.com

ISSN: 1110-0559, Vol. 41, No.2

\section{INTRODUCTION}

Nanotechnology is involved in different sciences with fast growing number of applications of engineered nanoparticles (NPs) in drug delivery systems, medical devices and some food products. The subsequent disposal of these engineered NPs into the environment allows for an increasing human exposure to such NPs. Moreover, their specific physicochemical properties at the nanoscale are expected to result in an increased reactivity with biological systems. So, despite their beneficial effects, engineered NPs of different types may represent a potential hazard to human health ${ }^{[1-3]}$.

According to American Society for Testing and
Materials $^{[4]}$, NPs are those particles with the length range of $1-100 \mathrm{~nm}$ in two or three dimensions. NPs have distinctive properties different from bulk-sized materials, including large surface area to volume ratios, high reactivity and strong interaction with biological matrices owing to their small sizes ${ }^{[5]}$.

Gold nanoparticles (GNPs) possess the talented therapeutic possibilities due to their unique properties such as the ease of synthesis, chemical stability and biocompatibility, in addition to a wide range of delivery targets ${ }^{[6]}$. GNPs have been found to be useful for the controlled release of many chemical agents such as amino $\operatorname{acids}^{[7]}$, antibiotics ${ }^{[8]}$, peptides ${ }^{[9]}$, anticancer $\operatorname{drugs}^{[10]}$,

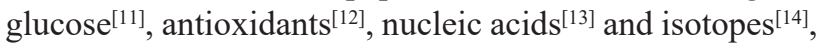
and they are also used in $\operatorname{cosmetics}^{[15]}$. 
GNPs can enter the body through inhalation, ingestion and $\operatorname{skin}^{[16]}$. The majority of the scientific reports that investigated the cellular impact of GNPs were in vitro, while fewer studies were conducted to investigate their impact in vivo ${ }^{[17]}$. Many studies have demonstrated a wide distribution of GNPs inside the living system, where the amount of their distribution in the body inversely correlated with the size of the particles ${ }^{[18,19]}$.

Gender differences were previously reported with orally administrated silver nanoparticles ${ }^{[20]}$. A two-fold higher concentration was detected in the kidneys of female experimental animals compared to male ones ${ }^{[21]}$. Although previous works have focused on examining the effect and distribution of GNPs in male kidney ${ }^{[19]}$, their effect and distribution in female kidney have not been yet thoroughly examined. Therefore, this work aimed to investigate the effect of different doses of GNPs on the renal cortex of adult female rats employing different histological and immunohistochemical techniques.

\section{MATERIALS AND METHODS}

Thirty adult female albino rats (140-160 grams) were kept in clean properly ventilated cages with free access to a balanced laboratory diet and water. They were acclimatized for 2 weeks before the experiment. The experiment was approved by the Local Ethics Committee of the National Research Centre (Giza, Egypt). The animals were randomly divided into three equal groups (10 rats each): Group I (Control group): animals of this group were orally administered $1 \mathrm{ml}$ of distilled water daily for 14 days. Group II and group III administered $40 \mu \mathrm{g}$ or $400 \mu \mathrm{g}$ gold nanoparticles/kg body weight, respectively in $1 \mathrm{ml}$ of distilled water daily for 14 days ${ }^{[5,19]}$.

Preparation of GNPs: The preparation of the colloidal GNPs was according to the standard citrate reduction route using Turkevich protocol ${ }^{[22,23]}$. Briefly, $0.1699 \mathrm{~g}$ of gold salt (HAuCL4) was added to $100 \mathrm{ml}$ of deionized water producing a faint yellowish solution, this solution was boiled for $45 \mathrm{~min}$ giving $0.5 \times 10-3 \mathrm{M}$ HAuCL4. $\mathrm{H} 2 \mathrm{O}$. One milliliter of the solution was transferred to 18 $\mathrm{ml}$ of double distilled water in a conical flask for heating and stirred vigorously, upon reaching the boiling point, one milliliter of $0.5 \%$ sodium citrate as a reducing agent was quickly added. The color of the solution gradually changed from the initial faint yellow to pale purple color. Heating continued for another $15 \mathrm{~min}$, the solution was removed from the heater and stirred for further $15 \mathrm{~min}$. The citrate-coated GNPs were stored at $4{ }^{\circ} \mathrm{C}$ in order to prevent aggregation. This method produces mono-disperse spherical gold nanoparticles in the range of $10-15 \mathrm{~nm}$ in diameter as detected through electron microscopic morphometric analysis.

At the end of the experiment, animals were euthanized using intraperitoneal injection of pentobarbital (40 $\mathrm{mg} / \mathrm{kg})^{[4]}$ during the same diestrous phase guided by vaginal smear. The kidneys were rapidly dissected and prepared for light and electron microscopic examination.

\section{For examination by light microscopy:}

Kidney specimens were fixed in $10 \%$ neutral buffered formalin, washed, dehydrated in ascending grades of ethanol, cleared in xylol and embedded in paraffin. Sections of $5 \mu \mathrm{m}$ thickness were stained with haematoxylin and eosin (H\&E) for the study of general histological features and Mallory's trichrome stain for detection of collagen fibers $^{[25]}$.

\section{For immunohistochemical staining with Tumor necrosis factor-alpha (TNF- $\alpha)$ :}

Sections of $5 \mu \mathrm{m}$ thickness were dewaxed, rehydrated, and washed with phosphate buffered saline (PBS) and then incubated with PBS containing 10\% normal goat serum. Sections were incubated with the rabbit polyclonal antibody against TNF- $\alpha$ (ab6671, Abcam, Cambridge, Massachusetts, USA) overnight in a humid chamber at $4^{\circ} \mathrm{C}$ and then incubated with biotinylated goat anti-rabbit $\mathrm{IgG}$ for $60 \mathrm{~min}$ at room temperature. Sections were incubated with a streptavidin-biotin-horseradish peroxidase complex for another $60 \mathrm{~min}$. The immunoreactivity was visualized using 3,3'-diaminobenzidine (DAB) hydrogen peroxide as a chromogen, sections were counterstained with Mayer's haematoxylin. The negative control sections were prepared by excluding the primary antibodies ${ }^{[26]}$. Positive controls for TNF- $\alpha$ were human tonsils (as provided by the manufacturer).

\section{For examination by transmission electron microscopy:}

Renal cortical specimens were divided into small pieces, processed for transmission electron microscopy and were embedded in epoxy resin mixture. Semithin sections $(1 \mu \mathrm{m}$ thick) were stained with $1 \%$ toluidine blue and examined by light microscope for proper orientation ${ }^{[27]}$. Ultrathin sections $(80-90 \mathrm{~nm})$ were stained with uranyl acetate and lead citrate, to be examined by JEOL-JEM-100 transmission electron microscope (Tokyo, Japan) at the Electron Microscopic Unit, Faculty of Medicine, Tanta University, Egypt.

\section{Morphometric analysis}

The images were obtained using a Leica microscope (DM3000, Leica, Germany) coupled to a CCD-camera (DFC-290, leica, Germany). The image analysis was done using Leica Qwin $500 \mathrm{C}$ image analyzer computer system (Leica Imaging System LTD., Cambridge, England) at Central Research Lab, Faculty of Medicine, Tanta University, Egypt. Ten different non-overlapping randomly-selected fields at a magnification of 400 were examined in each slide for:

1- The maximum glomerulus diameter $(\mu \mathrm{m})$ in H\&Estained sections

2- The mean area percentage (\%) of collagen fiber 
content in Mallory's trichrome-stained sections. Total area was measured by adjusting the color threshold while excluding the background and then the blue stained area was selected and measured to calculate the area percentage $(\%)=($ blue stained area/total area $) * 100$.

3- The mean color intensity of positive immunohistochemical reaction for TNF- $\alpha$ in DAB-stained sections. The color intensity was calculated by subtracting the color intensity of negative immunohistochemical control from the color intensity of positive stained specimen in serial sections.

\section{Statistical analysis}

The data were analyzed by using one-way analysis of variance (ANOVA) followed by Tukey's test for comparison between the groups using statistical package for social sciences statistical analysis software (version 11.5; SPSS Inc., Chicago, Illinois, USA). All values were expressed as mean \pm standard deviation. Differences were regarded as significant if probability value $p<0.05$ and highly significant if $p<0.001^{[28]}$.

\section{RESULTS} study.

No deaths were observed during the course of this

\section{Haematoxylin and Eosin (H\&E) staining:}

\section{Group I: (Control group):}

H\&E stained section from renal cortex of control group showed the well-known normal structure and revealed the presence of renal corpuscles and tubules. Each renal corpuscle was formed of a glomerulus surrounded by a double layered Bowman's capsule with a regular capsular space in between. The parietal layer was formed of a single layer of simple squamous cells, whereas the visceral layer was formed of podocytes with large and oval nuclei. The glomeruli were formed of tufts of capillaries lined by flat endothelial cells. Proximal convoluted tubules (PCTs) were observed with distinct brush borders, rounded central nuclei, acidophilic cytoplasm and apparent basal striations with ill-defined lateral borders. Distal convoluted tubules (DCTs) with a wider lumen and ill-defined brush borders. The amount of renal interstitium was sparse (Fig. 1).

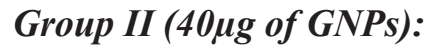

Section from renal cortex of group II revealed some apparent hypercellular glomeruli with congested capillaries. The cells of many PCTs were swollen with vacuolated cytoplasm and some pyknotic nuclei. Some DCTs showed exfoliated epithelial cells. Acidophilic casts were occasionally observed in some glomeruli and DCTs. Congested intertubular capillaries and focal mononuclear cells aggregations were frequently detected (Fig. 2).

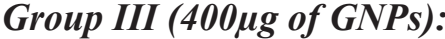

Section from renal cortex of group III revealed loss of the normal renal cortical architecture. Many apparent hypercellular glomeruli with extremely narrowed or totally obliterated glomerular spaces were observed. Most PCTs were severely distorted, their cells showed vacuolated cytoplasm and pyknotic nuclei. Many DCTs showed nuclei shed into the lumen and some karyolytic nuclei. Some tubules were totally distorted. Some extremely dilated congested intertubular blood vessels together with extensive mononuclear cellular aggregations were observed. Some blood vessels with thickened wall were frequently detected (Figs. 3, 4).

Morphometric analysis of the maximum glomerular diameter in group II showed a significant increase $(129.62 \pm 14.99)$ compared to the control group (116.34 \pm 12.05$)$. Moreover, group III showed a highly significant increase $(165.08 \pm 19.11)$ compared to the control (Table 1).

\section{Mallory's trichrome staining:}

Mallory's trichrome-stained sections from renal cortex of control group I showed thin blue-stained collagen fibers located around and within the renal corpuscles and around the tubules (Fig. 5). Sections from group II revealed excess collagen fiber deposits in the interstitium, around the tubules and also within the glomeruli (Fig. 6), while sections from group III showed massive collagen fiber deposition around the tubules and within the glomeruli, some blood vessels with thickened walls were frequently observed (Fig. 7).

Morphometric analysis of the mean area percentage of collagen fiber content in group II (11.58 \pm 2.98$)$ showed a significant increase compared to the control group (7.12 \pm 2.05$)$, moreover, group III $(25.31 \pm 3.69)$ showed a highly significant increase compared to the control group (Table 1, Histogram 1 ).

\section{TNF- $\alpha$ immunohistochemical staining:}

Immunostained renal cortical sections from control group showed an extremely faint reaction to TNF- $\alpha$ (Fig. 8 ), while sections from group II expressed an apparently moderate cytoplasmic reaction in the form of brown coloration in the glomeruli and both proximal and distal convoluted tubules (Fig. 9). Moreover, sections from group III expressed an apparently strong cytoplasmic reaction particularly in both proximal and distal convoluted tubules (Fig. 10)

Morphometric analysis of the mean color intensity of TNF- $\alpha$ positive immunoreaction in group II $(19.09 \pm 3.65)$ expressed a significant increase compared to the control group (14.17 \pm 2.19$)$, moreover, group III (30.14 \pm 4.03$)$ showed a highly significant increase compared to the control group (Table 1, Histogram 2). 


\section{Electron microscopic examination:}

\section{Group I: (Control group):}

Examination of ultrathin sections from the control group I revealed normal ultrastructural features of the renal corpuscles which were composed of visceral and parietal layers; the visceral layer was formed of podocytes with central large euchromatic nuclei. Podocytes had long primary processes giving rise to secondary processes that ended in feet-like processes separated by narrow slits bridged by a slit membrane. The glomerular blood capillaries were lined with fenestrated endothelium. The podocytes and glomerular capillaries shared a trilaminar basement membrane with a central electron-dense layer (lamina densa) and two electron-lucent layers (lamina rara) on both sides (Fig. 11). The parietal layer of Bowman's capsule was lined with flat squamous cells separated from podocytes by Bowman's space (Fig. 12).

The cells of the proximal convoluted tubules (PCTs) were cuboidal in shape with numerous apical microvilli, euchromatic nuclei, and basal infoldings of plasma membrane with many basally located mitochondria (Fig. 13). Cells of distal convoluted tubules (DCTs) had numerous basal enfoldings with elongated mitochondria in between. DCTs cells appeared smaller than those of the proximal ones, with few or no microvilli (Fig. 14).

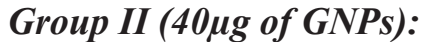

Examination of ultrathin sections from group II showed some narrowing in the glomerular capsular spaces (Fig. 15). Podocytes appeared large with irregular nuclei, while podocytic processes showed distortion and effacement.
Multiple intraglomerular mesangial cells were observed. Some gold nanoparticles mainly resided in the podocytic terminal processes (Figs. 15 and 16).

Some cells of PCTs showed irregularly shaped nuclei, variably sized and shaped mitochondria. Some lysosomes and vacuoles were observed. Thickening of basal lamina was detected in some PCTs in addition to abundant underlying interstitial cells (Fig. 17). Cells of DCTs showed numerous variably shaped mitochondria, some lysosomes and vacuoles. Focal thickening of the basal lamina was observed (Fig. 18).

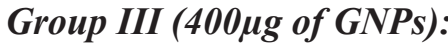

Examination of ultrathin sections from group III revealed podocytes with irregular or small heterochromatic nuclei were observed (Fig. 19). Distortion and effacement of the podocytic processes were noticed where many gold nanoparticles resided. Numerous intraglomerular mesangial cells with dark nuclei were observed (Fig. 20).

Some cells of PCTs showed small nuclei, variably sized and shaped mitochondria with loss of their basal orientation. Focal areas of rarefied cytoplasm, many electron-dense bodies; mostly lysosomes in addition to apical vacuoles were observed. Prominent thickening of basal lamina was detected in some PCTs. Gold nanoparticles were clearly observed in the cytoplasm (Fig. 21). Cells of DCTs showed dark small irregular nuclei, numerous abnormally shaped disoriented mitochondria, lysosomes and vacuoles. An irregularly thickened basal lamina was observed in some DCTs. Moreover, gold nanoparticles were clearly observed in the cytoplasm (Fig. 22).

Table 1: Morphometeric analysis of the renal cortex specimens from all groups

\begin{tabular}{lccc}
\hline Parameters & Group I & Group II & Group III \\
\hline Mean maximum glomerular diameter $(\mu \mathrm{m})$ & $116.34 \pm 12.05$ & $129.62 \pm 14.99^{*}$ & $165.08 \pm 19.11^{* *}$ \\
Mean area percentage (\%) of collagen fiber & $7.12 \pm 2.05$ & $11.58 \pm 2.98^{*}$ & $25.31 \pm 3.69^{* *}$ \\
Mean color intensity of TNF- $\alpha$ immunoreaction & $14.17 \pm 2.19$ & $19.09 \pm 3.65^{*}$ & $30.14 \pm 4.03^{* *}$ \\
\hline
\end{tabular}

Data are expressed as mean \pm standard deviation, $* P<0.05$ is significant, $* * P<0.001$ is highly significant versus control. 


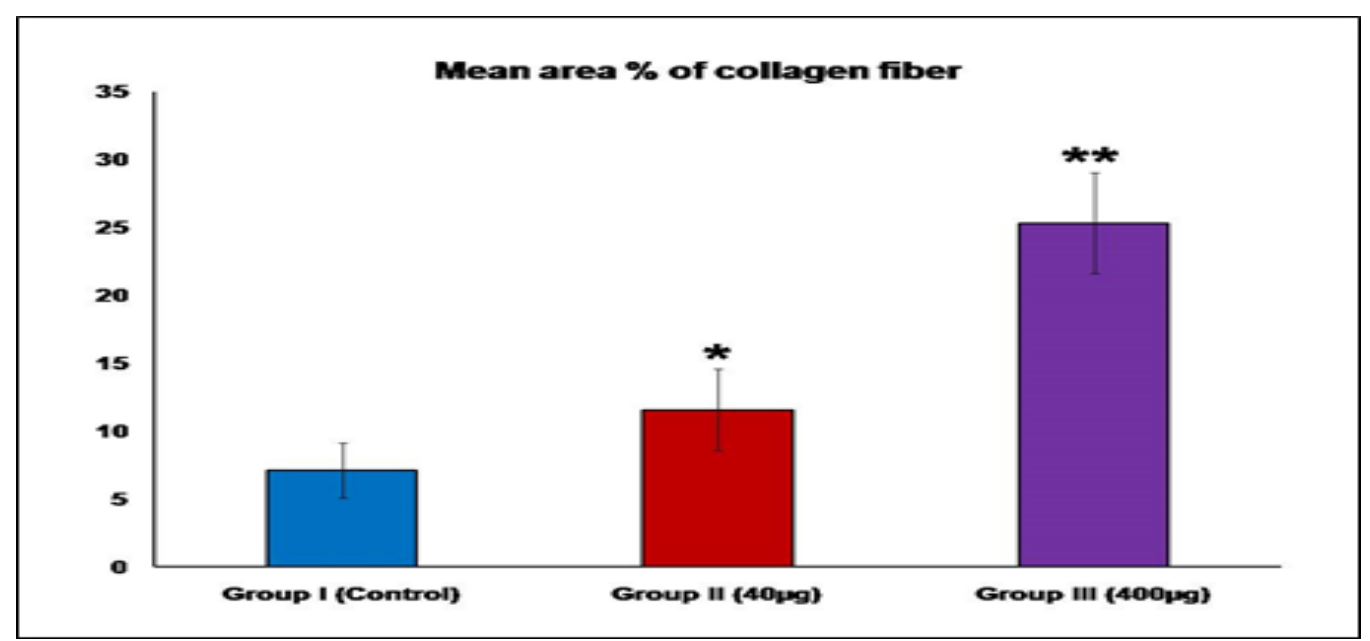

Histogram 1: The mean area $\%$ of collagen fiber in all animal groups.

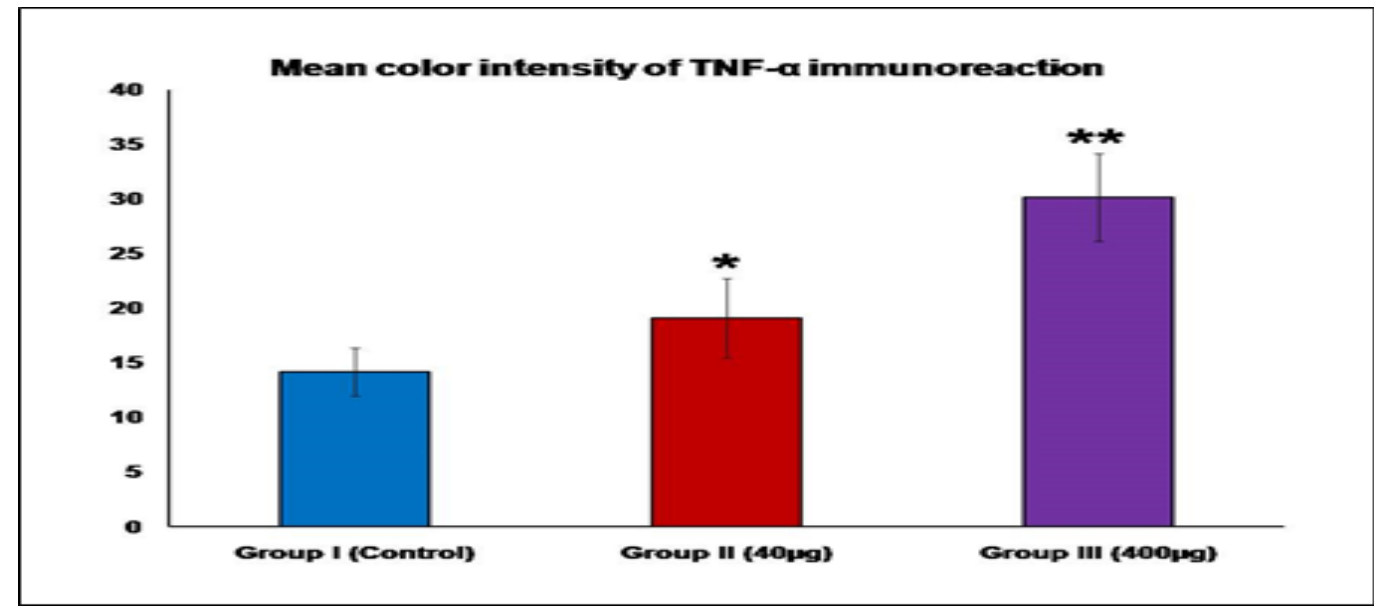

Histogram 2: The mean color intensity of TNF- $\alpha$ immunoreaction in all animal groups.

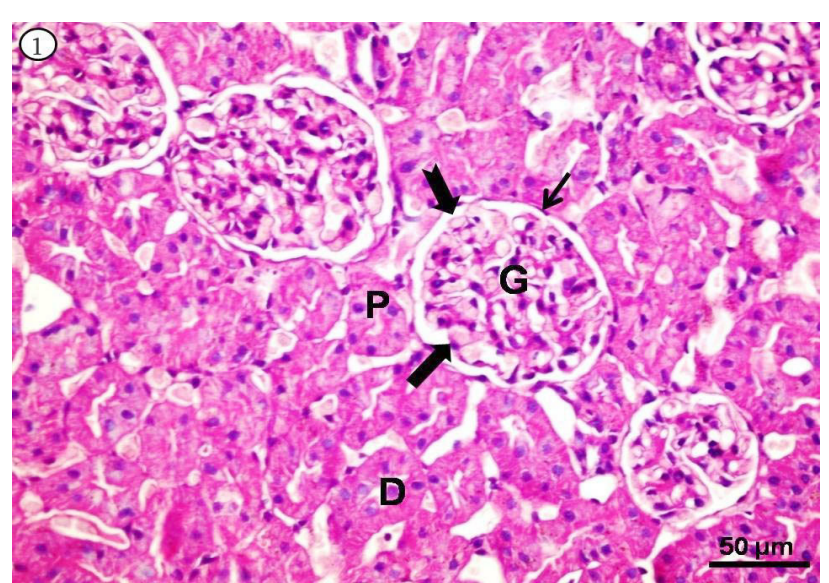

Fig. 1: A photomicrograph of the renal cortex of control group showing glomeruli $(\mathrm{G})$ formed of a tuft of capillaries surrounded with Bowman's capsule formed of a parietal simple squamous epithelium (thin arrow) and visceral podocytes (thick arrow) with regular capsular space in between (notched arrow). The Proximal convoluted tubules $(\mathrm{P})$ have narrow lumen and distinct brush border. Distal convoluted tubules (D) have wider lumen and less distinct brush border.

$(\mathrm{H} \& \mathrm{E} \times 400$, scale bar $=50 \mu \mathrm{m})$

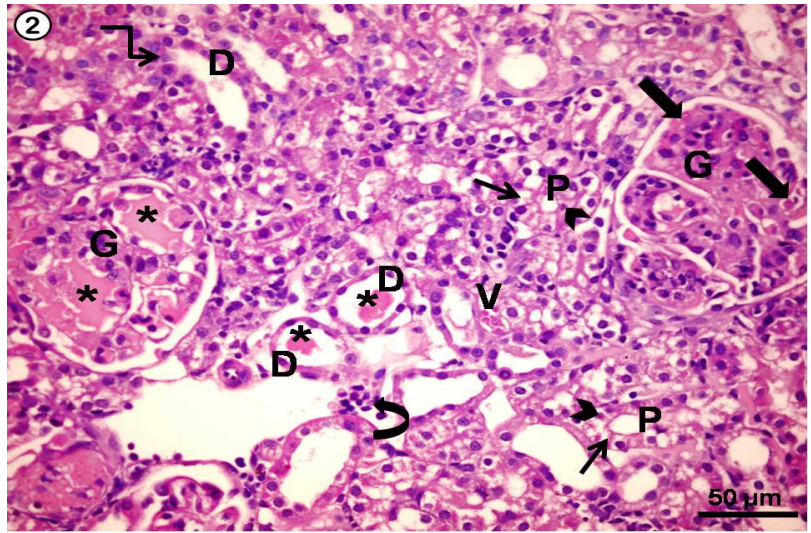

Fig. 2: A photomicrograph of the renal cortex of group II $(40 \mu \mathrm{g})$, showing apparent hypercellular glomeruli (G) with congested capillaries (thick arrows). The cells of many PCTs (P) are swollen with vacuolated cytoplasm (thin arrows) and pyknotic nuclei (arrow heads). Some DCTs (D) show exfoliated epithelial cells (angular arrow). Notice acidophilic casts in some glomeruli and DCTs (asterisks). Congested intertubular capillaries are detected (V). Focal mononuclear cells aggregations are observed (curved arrow).

$(\mathrm{H} \& \mathrm{EX} 400$, scale bar $=50 \mu \mathrm{m})$ 


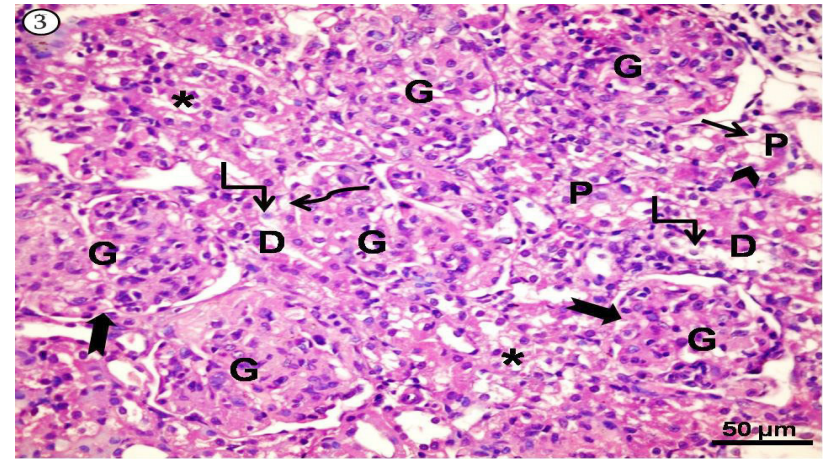

Fig. 3: A photomicrograph of the renal cortex of group III (400 $\mu \mathrm{g}$ ), showing loss of the normal cortical architecture. Many apparent hypercellular glomeruli (G) with extremely narrowed or totally obliterated glomerular spaces (notched arrows) are observed. Most PCTs (P) are severely distorted, and their cells show vacuolated cytoplasm (thin arrow) and pyknotic nuclei (arrow head). Many DCTs (D) show nuclei shed into the lumen (angular arrow) and karyolytic nuclei (wavy arrow). Some tubules are totally distorted (asterisks). (H\&EX400, scale bar $=50 \mu \mathrm{m})$

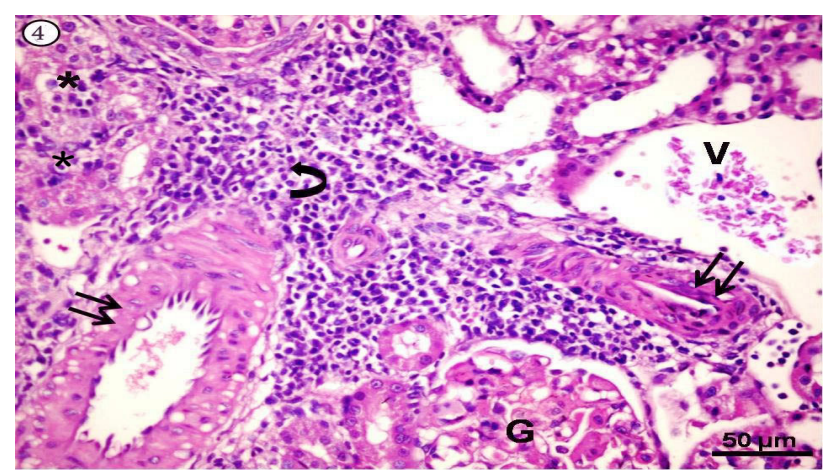

Fig. 4: A photomicrograph of the renal cortex of group III (400 $\mu \mathrm{g})$, showing apparent hypercellular glomeruli $(\mathrm{G})$, extremely dilated congested intertubular blood vessels (v). Extensive mononuclear cellular aggregations (curved arrow). Notice blood vessels with thickened wall (double thin arrows). Some tubules are totally distorted (asterisks). $\quad(H \& E X 400$, scale bar $=50 \mu \mathrm{m})$

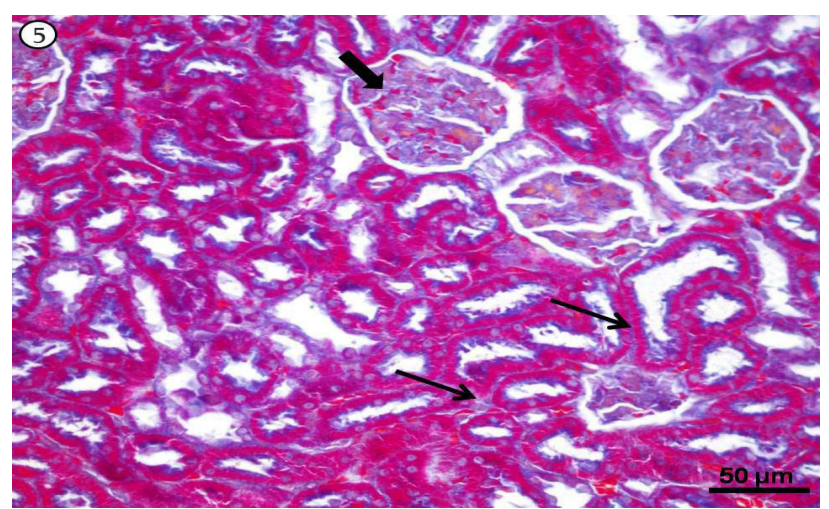

Fig. 5: A photomicrograph of the renal cortex of control group showing thin blue-stained collagen fibers around and within the renal corpuscles (thick arrow) and around the tubules (thin arrows). (Mallory's trichrome stain X400, scale bar $=50 \mu \mathrm{m}$ )

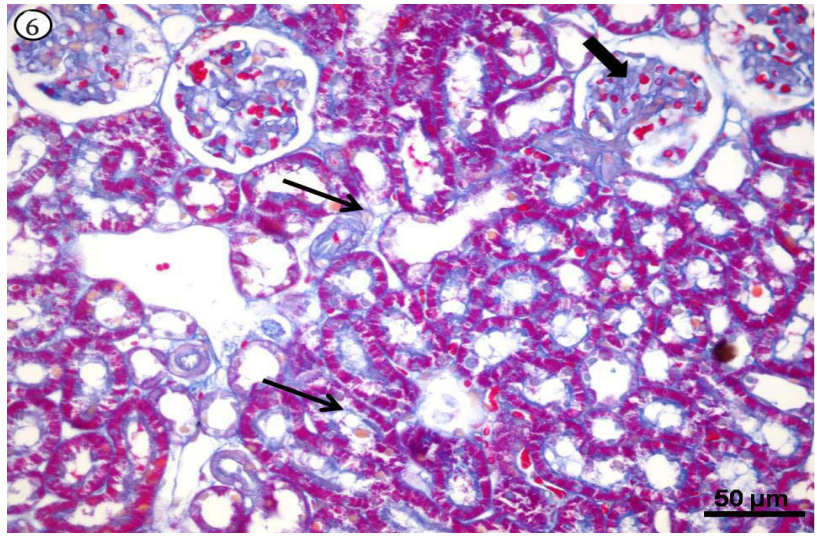

Fig. 6: A photomicrograph of the renal cortex of group II $(40 \mu \mathrm{g})$, showing excess blue-stained collagen fibers around and within the renal corpuscles (thick arrow) and around the tubules (thin arrows). (Mallory's trichrome stain X400, scale bar $=50 \mu \mathrm{m}$ )

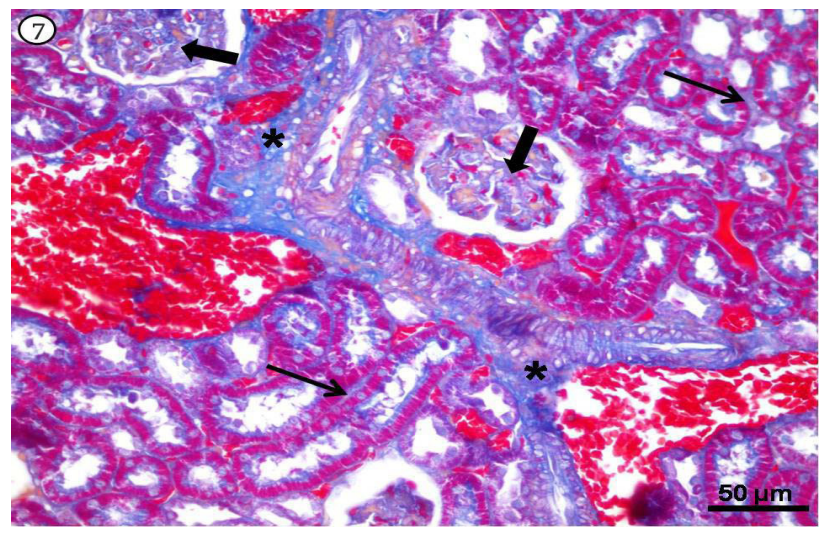

Fig. 7: A photomicrograph of the renal cortex of group III (400 $\mu \mathrm{g}$ ), showing massive deposition of collagen fibers around and within the renal corpuscles (thick arrows) and around the tubules (thin arrows), Notice focal areas of fibrosis mainly around blood vessels (asterisks). (Mallory's trichrome stain X400, scale bar $=50 \mu \mathrm{m})$

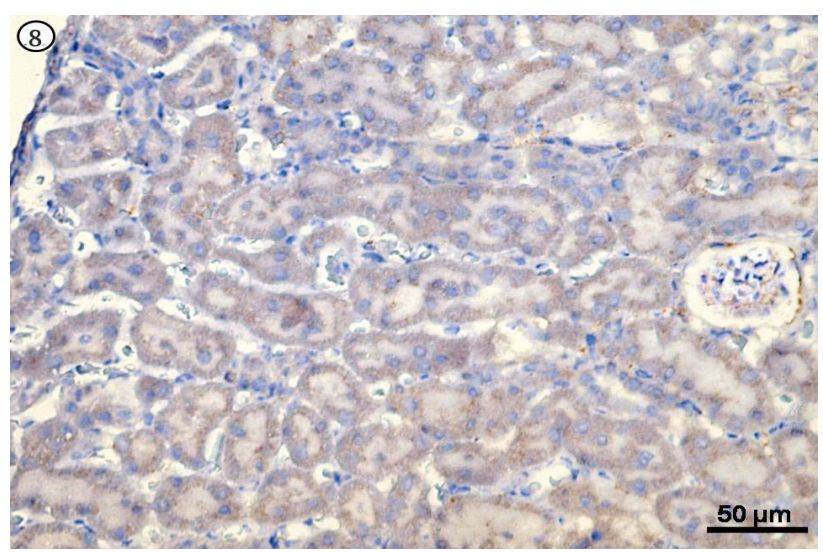

Fig. 8: A photomicrograph of the renal cortex of control group showing an extremely faint reaction to TNF-alpha in the glomeruli and convoluted tubules (TNF-alpha immuostainingX400, scale bar $=50 \mu \mathrm{m}$ ) 


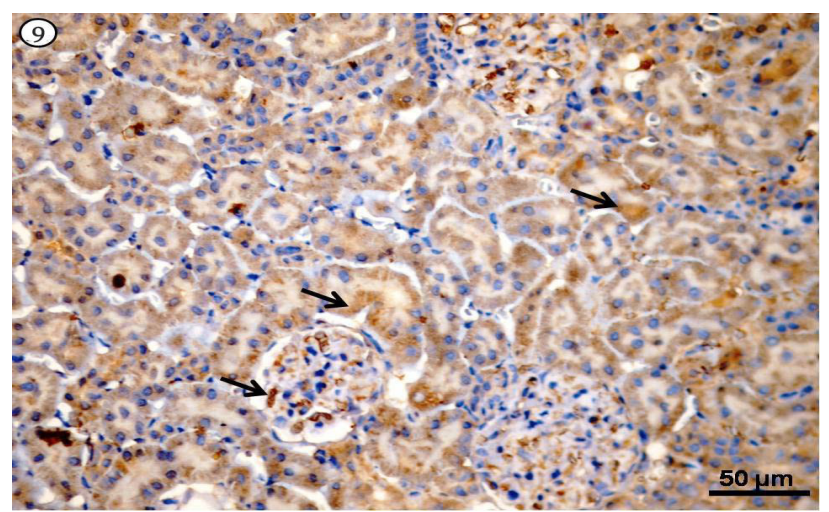

Fig. 9: A photomicrograph of the renal cortex of group II (40 $\mu \mathrm{g}$ ), showing moderate cytoplasmic reaction in the form of brown coloration in glomeruli and both proximal and distal convoluted tubules (arrows). (TNF-alpha immuostainingX400, scale bar $=50 \mu \mathrm{m})$

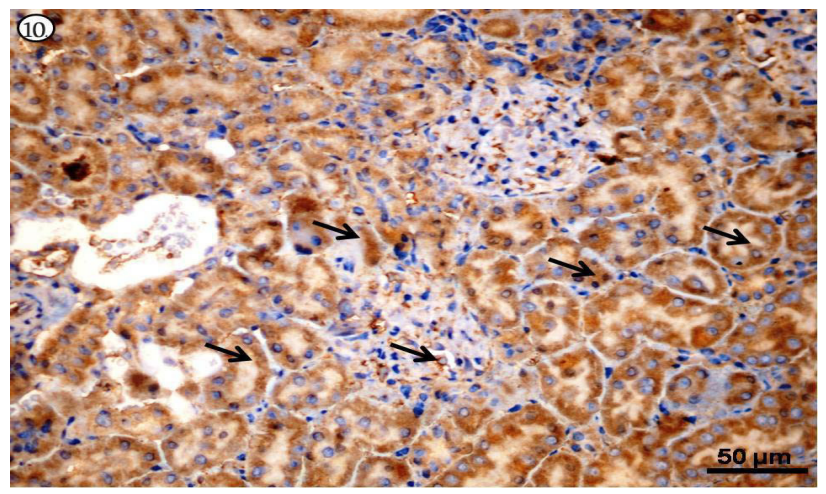

Fig. 10: A photomicrograph of the renal cortex of group III $(400 \mu \mathrm{g})$, showing strong cytoplasmic reaction in the form of brown coloration in glomeruli but mainly in both proximal and distal convoluted tubules (arrows). (TNF-alpha immuostainingX400, scale bar $=50 \mu \mathrm{m}$ )

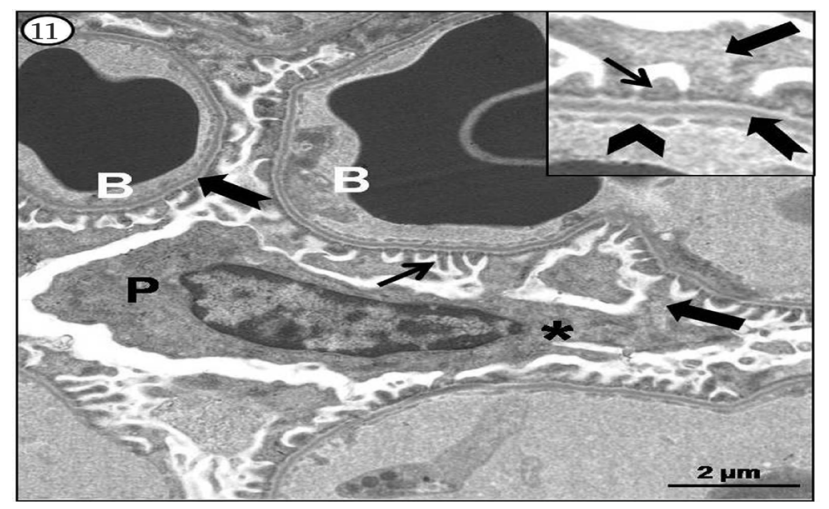

Fig. 11: An electron micrograph of the renal cortex of control group showing podocyte $(\mathrm{P})$ with primary process (asterisk), secondary processes (thick arrows) ending in feet process (thin arrows) resting on the glomerular basement membrane (notched arrows) showing a central electron dense lamina densa and lamina rarae on both sides. The inset shows a higher magnification of the glomerular basement membrane. Notice fenestrated endothelium (arrow head) of glomerular blood capillaries (B). (TEMX14600, InsetX29200, scale bar $=2 \mu \mathrm{m}$ )

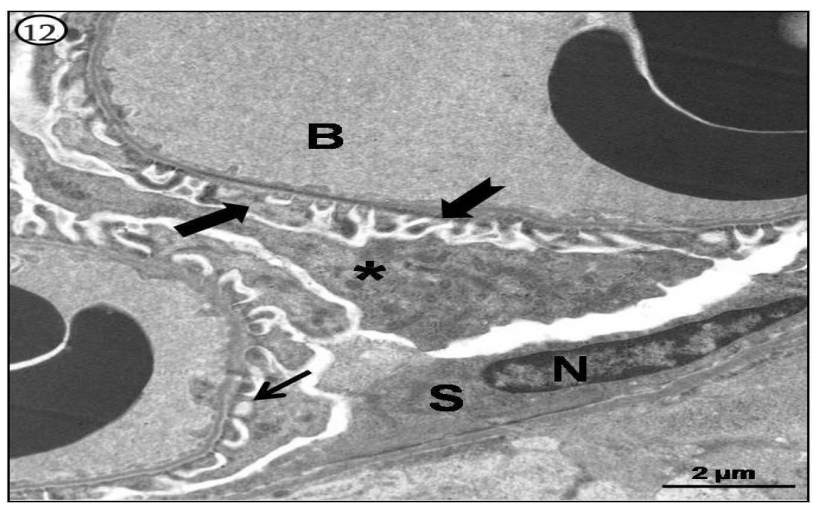

Fig. 12: An electron micrograph of the renal cortex of control group showing parietal layer of Bowman's capsule lined by squamous cells $(\mathrm{S})$ with flat elongated nuclei $(\mathrm{N})$. Notice a primary process (asterisk) of a podocyte and secondary processes (thick arrow) ending in feet process (thin arrow) resting on the glomerular basement membrane (notched arrow) separating it from glomerular blood capillary (B). (TEMX14600, scale bar $=2 \mu \mathrm{m})$

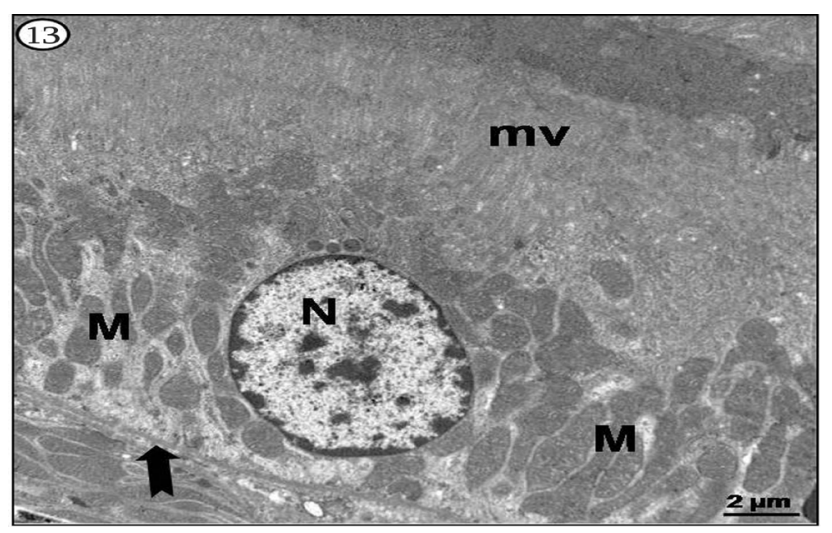

Fig. 13: An electron micrograph of the renal cortex of control group, showing cells of a proximal convoluted tubule with apical microvilli $(\mathrm{mv})$, euochromatic nucleus $(\mathrm{N})$ and basal mitochondria (M) resting on basement membrane (notched arrow).

(TEMX8780, scale bar $=2 \mu \mathrm{m})$

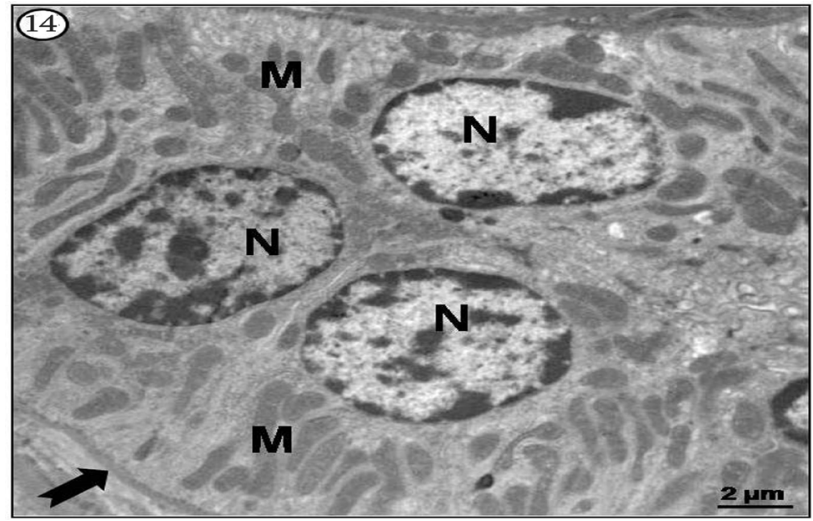

Fig. 14: An electron micrograph of the renal cortex of control group, showing cells of a distal convoluted tubule with euchromatic nucleus $(\mathrm{N})$ and basal mitochondria $(\mathrm{M})$ resting on basement membrane (notched arrow). (TEMX8780, scale $\mathrm{bar}=2 \mu \mathrm{m}$ ) 


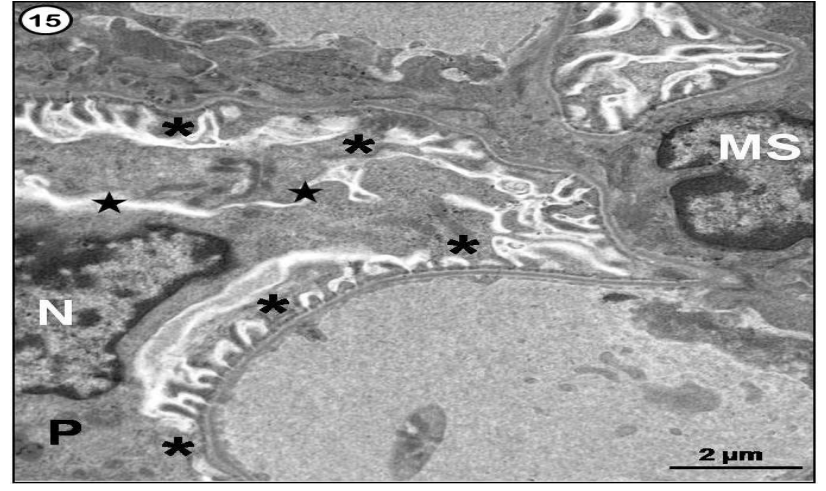

Fig. 15: An electron micrograph of the renal cortex of group II $(40 \mu \mathrm{g})$ showing some narrowing in the glomerular capsular spaces (stars). A large podocyte $(\mathrm{P})$ with irregular nucleus $(\mathrm{N})$, distortion and effacement of the podocytic processes (asterisks) is observed. An intraglomerular mesangial cell (MS) with irregular nucleus is seen. (TEMX14600, scale bar $=2 \mu \mathrm{m}$ )

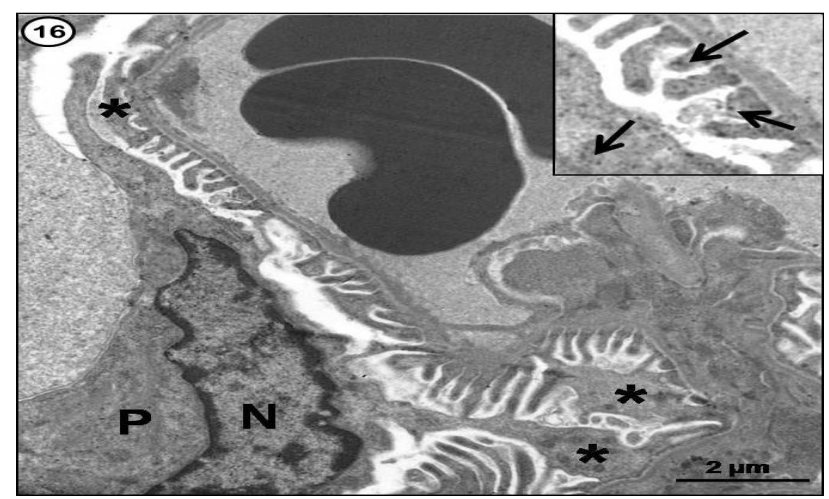

Fig. 16: An electron micrograph of the renal cortex of group II $(40 \mu \mathrm{g})$ showing a large podocyte $(\mathrm{P})$ with irregular nucleus $(\mathrm{N})$, distortion and effacement of the podocytic processes (asterisks). The inset shows a higher magnification of the podocytic processes where gold nanopaticles mainly reside (thin arrows). (TEMX14600, InsetX29200, scale bar $=2 \mu \mathrm{m}$ )

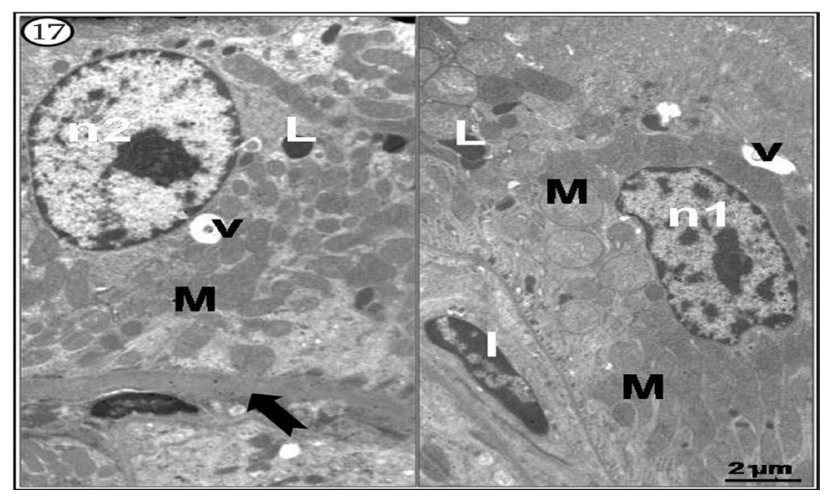

Fig. 17: An electron micrograph of the renal cortex of group II $(40 \mu \mathrm{g})$ showing a cell of proximal convoluted tubule with irregular nucleus (n1). Variably sized and shaped mitochondria (M) are observed. Some lysosomes (L) and vacoules (v) are seen. Notice thickened basement membrane (notched arrow) and some underlying interstitial cells (I). Notice another cell of a proximal convoluted tubule having an apparently normal nucleus (n2). (TEMX8780, scale bar $=2 \mu \mathrm{m}$ )

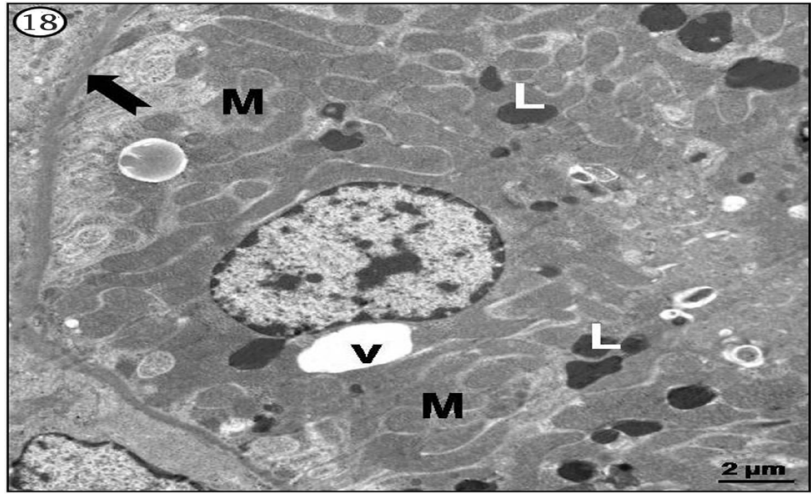

Fig. 18: An electron micrograph of the renal cortex of group II $(40 \mu \mathrm{g})$ showing a cell of distal convoluted tubule with numerous variably shaped mitochondria (M), numerous lysosomes (L) and some vacuoles (v). Notice focal thickening of the basal lamina (notched arrow).

(TEMX8780, scale bar $=2 \mu \mathrm{m}$ )

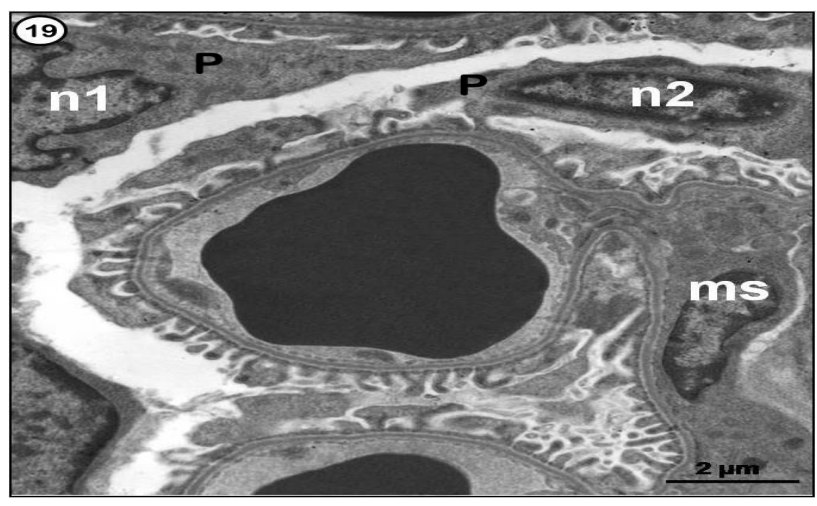

Fig. 19: An electron micrograph of the renal cortex of group III showing podocyte $(\mathrm{P})$ with irregular nucleus $(\mathrm{n} 1)$ or small dense nucleus (n2), interruption, distortion and effacement of the podocytic processes (asterisks). Notice focal irregularity in the glomerular basement membrane (notched arrow) and mesangial cells with dark nuclei in the renal glomerular capillaries (ms). (TEMX14600, scale bar $=2 \mu \mathrm{m})$

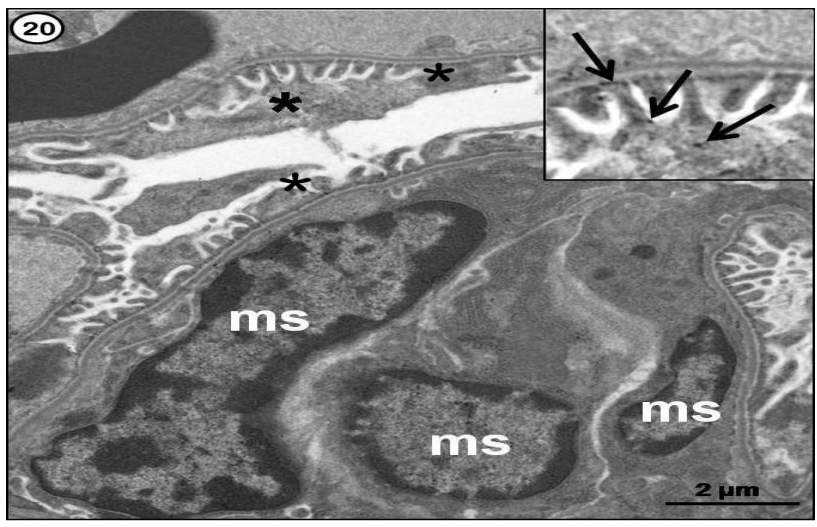

Fig. 20: An electron micrograph of the renal cortex of group III $(400 \mu \mathrm{g})$ showing numerous mesangial cells with dark nuclei in the renal glomerular capillaries (ms). Distortion and effacement of the podocytic processes (asterisks) is noticed. The inset shows a higher magnification of the podocytic processes where gold nanoparticles (thin arrows) are detected. (TEMX14600, InsetX29200, scale bar $=2 \mu \mathrm{m}$ ) 


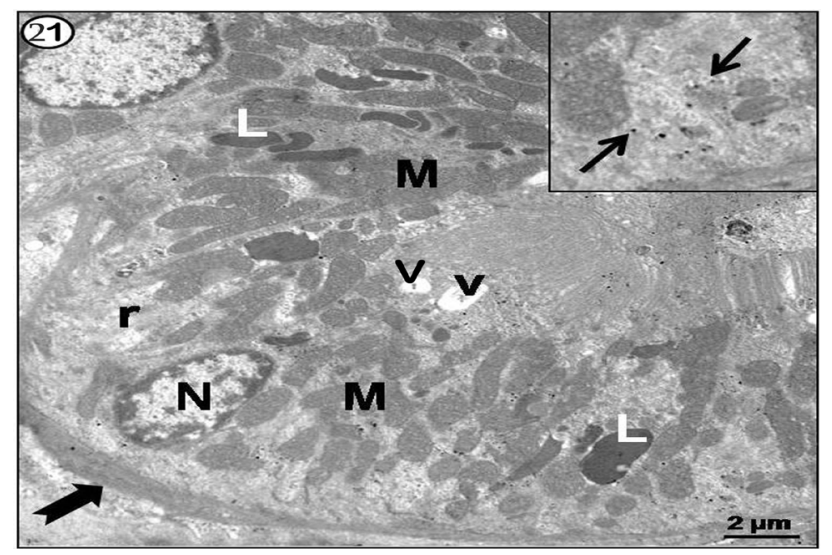

Fig. 21: An electron micrograph of the renal cortex of group III $(400 \mu \mathrm{g})$ showing a cell of proximal convoluted tubule with small nucleus $(\mathrm{N})$. Areas of rarefied cytoplasm (r) and variably sized and shaped mitochondria $(\mathrm{M})$ with loss of their basal orientation are observed. Some lysosomes (L) and vacoules (v) are seen. Notice the thickened basement membrane (notched arrow). The inset shows a higher magnification of part of the cytoplasm of a cell of proximal convoluted tubule where gold nanoparticles are detected (thin arrows). (TEMX8780, InsetX17500, scale bar $=2 \mu \mathrm{m}$ )

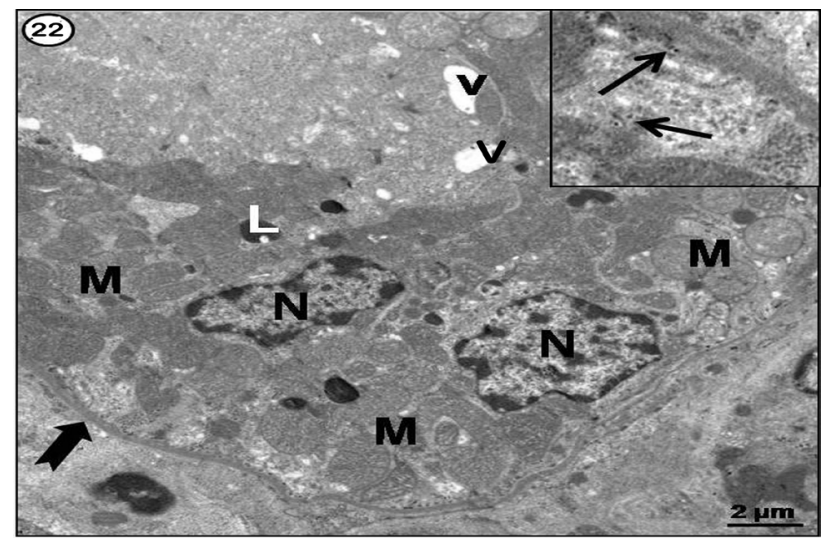

Fig. 22: An electron micrograph of the renal cortex of group III $(400 \mu \mathrm{g})$ showing cells of distal convoluted tubule with dark small nuclei with irregular outlines $(\mathrm{N})$, numerous variably shaped disoriented mitochondria (M), lysosomes (L) and some vacuoles (v). Focal thickening of the basal lamina (notched arrow) is observed. The inset shows a higher magnification of part of the cytoplasm of cell of a distal convoluted tubule where gold nanoprticles are detected (thin arrows). (TEMX8780, InsetX17500, scale bar $=2 \mu \mathrm{m}$ ).

\section{DISCUSSION}

Gold nanoparticles (GNPs) have been extensively developed for various biomedical applications such as biosensors, immunoassays, genomics, photo thermolysis of cancer cells, microorganisms detection and control, imaging and monitoring of biological cells and tissues, and targeted drug delivery ${ }^{[2,30]}$.

Although the population exposed to GNPs continues to grow with the increasing new applications, GNPs remain a controversial research area as regards their toxicity to biological systems. Toxicity of GNPs had been reported both in vitro and in vivo ${ }^{[31,32]}$. However, conflicting results were reported owing to the differences in experimental protocols, such as the used cell lines or animal models, particle size, surface chemistry and concentration $^{[33,34]}$. Most in vivo toxicity studies of GNPs have been investigated by intraperitoneal or intravenous injection ${ }^{[35]}$. However, the oral toxicity of GNPs is of particular concern to ensure public and consumer health.

Kidney is a potential target of GNPs because it is one of the vital organs in addition to its innate function as a blood filter ${ }^{[36]}$. About $90 \%$ of the total renal blood flow enters the renal cortex via the bloodstream, thus, a relative high concentration of nanoparticles might target the cortex rather than the medulla ${ }^{[37]}$. Female population is mostly vulnerable and deserves special attention as toxicity in this group could affect both female reproductivity and fetal development ${ }^{[38]}$. Therefore, the present study aimed to investigate the effect of different doses of orally administered GNPs on the structure of renal cortex of adult female albino rats employing different histological and immunohistochemical techniques.

Results from the present study demonstrated that oral administration of $10 \mathrm{~nm}$ GNPs caused dose-dependent structural changes in the renal cortex in the form of distorted and degenerated PCTs and DCTs with vacuolated cytoplasm and many nuclear changes consistent with the findings of other study ${ }^{[39]}$. The cytoplasmic vacuolation may be due to the disturbance of renal cell membrane function leading to massive influx of water and $\mathrm{Na}+$ ions. Moreover, the tubular degeneration could be related to fluid homeostasis disturbance induced by these fine GNPs leading to an increase of intracellular water ${ }^{[40]}$. In addition, these alterations might be accompanied by lysosomal hydrolytic enzymes leakage leading to cytoplasmic degeneration and macromolecular crowding ${ }^{[41]}$.

The current work showed that exposure to GNPs induced nuclear polymorphism mainly pyknosis and karyolysis. The pyknotic nuclei exhibited condensation of the chromatin together with irregular nuclear membranes, which is similar to the nuclei of cells undergoing necrosis or apoptosis, while karyolysis is a sort of complete dissolution of the chromatin matter of a dying cell[ ${ }^{[42]}$. The induced necrosis by GNPs exposure may indicate the effect of these fine particles in organelles swelling, lyses and dissolution of renal cells nuclei ${ }^{[43]}$. In addition, the hyaline casts observed in the lumen of some renal tubules of GNPstreated rats could indicate a renal injury associated with protein metabolism disturbances ${ }^{[39]}$.

Morphometric results of the current study revealed a dose-dependent increase in the maximum glomerular diameter, implying an eminent decline in renal function, 
where enlarged glomeruli were previously reported to more susceptible to subsequent renal injury and functional decline ${ }^{[4]}$, and therefore used as a histological prognostic indicator of a long-term evolution of a renal histopathology ${ }^{[45]}$. Moreover, extremely narrowed or totally obliterated glomerular spaces were observed during this study. Terentyuk et al. ${ }^{[46]}$ have reported the proliferation of epithelial cells of Bowman's capsule by GNPs, where small sized particles showed more effect than larger ones. Moreover, some DCTs showed exfoliated epithelial cells. According to Inumaru et al. ${ }^{[47]}$, this alteration might indicate that GNPs affect renal cells adhesion and induce cell-cell junction disruption. They added that oxidative stress is a crucial factor to induce cell-cell dissociation.

The present study revealed different signs of inflammation that were increased with increasing the dose of GNPs in the form of mononuclear cellular infiltration along with dilated congested blood vessels and a significant dose-dependent increase in the collagen deposition indicating fibrosis in GNPs treated groups compared to the control group. The presence of inflammatory cells in the renal tissues of rats exposed to GNPs might suggest that these particles could interact with proteins and enzymes of the renal interstitial tissue interfering with the antioxidant defense mechanism leading to reactive oxygen species generation, thus imitating an inflammatory response ${ }^{[48]}$. These inflammatory signs were consistent with the immunohistochemical results that revealed a significant dose-dependent up-regulation of the proinflammatory cytokine TNF- $\alpha$ immunoexpression in GNPs treated groups compared to control group. The immunoexpression of TNF- $\alpha$ was measured to detect the inflammation mediated toxicity of GNPs and to predict their immunomodulatory effect. TNF- $\alpha$ not only plays a significant role in the inflammatory process, but may has immunoregulatory functions at the same time. Moreover, delivery of nanoparticles through oral routes brings them in contact with the mucosa-associated lymphoid tissues causing an interaction with the residing macrophages or lymphocytes with possibilities of subsequent transportation of cells or the immune products to the circulation and other body tissues ${ }^{[49]}$. Yen et al. ${ }^{[50]}$ have reported the induction of more immunological responses with smaller GNPs than with the larger ones.

Ultrastructural findings of the current study supported the light microscopic ones. Additionally, $10 \mathrm{~nm}$ GNPs were detected in the podocytic terminal processes and in the cytoplasm of both PCTs and DCTs. These findings are in parallel with the results of other investigators ${ }^{[51]}$ who concluded that tissue distribution of GNPs is sizedependent, where the small GNPs possess the most widespread organ distribution and can be cleared by renal filtration and urinary excretion ${ }^{[52]}$. It was suggested that NPs smaller than $5.5 \mathrm{~nm}$ can be rapidly and efficiently metabolized by renal clearance, while those larger than 15 $\mathrm{nm}$ can prevent the renal excretion and could accumulate in the liver and spleen ${ }^{[33-55]}$. Other studies declared that NPs smaller than $50 \mathrm{~nm}$ are capable of entering the cells can even move out of the blood vessels if their size is less than $20 \mathrm{~nm}^{[56]}$. On the other hand, accumulation of GNPs in cells other than macrophages suggested that inert GNPs do not penetrate cell membranes by nonendocytotic mechanisms ${ }^{[57]}$. However, the presence of NPs in erythrocytes indicates their ability to cross the cell membrane by processes other than phagocytosis since erythrocytes do not have phagocytotic receptors ${ }^{[58,}{ }^{59]}$. Diffusion, transmembrane channels, adhesive interactions, or other undefined transmembrane processes might play a role in this cellular uptake ${ }^{[60]}$.

In addition to the GNPs-size, the toxicity of GNPs is also based on their surface coating ${ }^{[61,62]}$, whereas GNPs without any binding agent did not show any toxicity ${ }^{[63]}$. Endocytosis plays an important role in the interaction between GNPs and cells, recent quantitative evaluation revealed that the surface coating on GNPs could modulate the endocytotic uptake pathways and cellular trafficking of the NPs. Naked GNPs were taken up by macropinocytosis as well as by clathrin-mediated and caveolin-mediated endocytosis. The difference in uptake is due to interactions with different proteins or lipids related to mechanisms of endocytosis ${ }^{[19,64,65]}$. Moreover, variations in plasma proteins and hormonal levels were suggested to account for the different physiological responses to nanoparticles in males and females, most probably due to the interactions between blood plasma and nanoparticles ${ }^{[66]}$.

Toxicity of GNPs was explained in terms of intracellular release of the corresponding toxic gold ions ${ }^{[67]}$. Intracellular gold ions strongly inhibit thioredoxin reductase enzyme leading to mitochondrial membrane depolarization and inactivation of mitochondrial enzymes ${ }^{[68]}$. This, in turn, causes several toxic mainstream events, including alteration of cellular redox balance, increase of physiological ROS levels, and occurrence of apoptosis ${ }^{[69]}$.

\section{CONCLUSION}

Histological and immunohistochemical findings obtained from this study demonstrate that repeated oral administration of GNPs induced their dose-dependent deposition in renal cortical tissue as well as dose-dependent structural alterations and various degrees of inflammation in adult female albino rat. So, administration of drugloaded gold nanoparticles for females require particular caution because of their special vulnerability, especially regarding the dose.

\section{CONFLICT OF INTEREST}

There are no conflicts of interest. 


\section{ACKNOWLEDGEMENT}

The authors wish to express their deepest gratitude to Dr. Marwa A. A. Ibrahim from the Department of Histology, Faculty of Medicine, Tanta University for her invaluable contributions to the current work.

\section{REFERENCES}

1. Cai W, Gao T, Hong H, Sun J. Application of Au nanoparticles in cancer nanotechnology. Nanotech Sci Appl. 2008; 1: 17-32.

2. De Jong WH, Burger MC, Verheijen MA, Geertsma RE. Detection of the presence of gold nanoparticles in organs by transmission electron microscopy. Materials 2010; 3: 4681-4694.

3. Babadi VY, Najafi L, Najafi A, Gholami H, Zarji ME, Golzadeh J, Amraie E, Shirband A. Evaluation of iron oxide nanoparticles effects on tissue and enzymes of liver in rats. J Pharm Biomed Sci. 2012; 23(23): 1-5.

4. ASTM International E 245606- Terminology for nanotechnology. West Conshohocken, PA: ASTM International, 2006. Pages 1-4.

5. Zhang $\mathrm{XD}, \mathrm{Wu} \mathrm{HY}$, Wu $\mathrm{D}$, Wang $\mathrm{YY}$, Chang JH, Zhai ZB, Meng AM, Liu PX Zhang LA, Fan FY. Toxicologic effects of gold nanoparticles in vivo by different administration routes. Int $\mathrm{J}$ Nanomedicine 2010; 5: 771-781.

6. Panchapakesan B, Book-Newell B, Sethu P, Rao M, Irudayaraj J. Gold nanoprobes for theranostics. Nanomedicine (Lond). 2011; 6(10): 1787-1811.

7. Ipe BI, Mahima S, Thomas KG. Light-induced modulation of self-assembly on spiropyrancapped gold nanoparticles: a potential system for the controlled release of amino acid derivatives. $\mathbf{J}$ Am Chem Soc. 2003; 125(24): 7174-7175.

8. Tom RT, Suryanarayanan V, Reddy PG, Baskaran S, Pradeep T. Ciprofloxacin-protected gold nanoparticles. Langmuir 2004; 20(5): 1909-1914.

9. Bastús NG, Sánchez-Tilló E, Pujals S, Farrera C, Kogan MJ, Giralt E, Celada A, Lloberas J, Puntes V. Peptides conjugated to gold nanoparticles induce macrophage activation. Mol Immunol. 2009; 46(4): 743-748.

10. Craig GE, Brown SD, Lamprou DA, Graham D, Wheate NJ. Cisplatin-tethered gold nanoparticles that exhibit enhanced reproducibility, drug loading, and stability: a step closer to pharmaceutical approval? Inorganic Chemistry 2012; 51(6): 3490-3497.

11. Song K, Xu P, Meng Y, Geng F, Li J, Li Z, Xing J, Chen J, Kong B. Smart gold nanoparticles enhance killing effect on cancer cells. Int J Oncol. 2013; 42(2): 597-608.

12. Simpson CA, Salleng K J, Cliffel DE, Feldheim DL. In vivo toxicity, biodistribution, and clearance of glutathionecoated gold nanoparticles Nanomedicine 2013; 9(2): 257-263.

13. Ghosh R, Singh LC, Shohet JM, Gunaratne PH A gold nanoparticle platform for the delivery of functional microRNAs into cancer cells. Biomaterials 2013; 34(3): 807-816.

14. Guerrero S, Herance JR, Rojas S, Mena JF, Gispert JD, Acosta GA, Albericio F, Kogan MJ. Synthesis and in vivo evaluation of the biodistribution of a 18F-labeled conjugate gold-nanoparticle-peptide with potential biomedical application. Bioconjug Chem. 2012; 23(3): 399-408.

15. El-Sayed IH, Huang X, El-Sayed MA. Selective laser photo-thermal therapy of epithelial carcinoma using anti-EGFR antibody conjugated gold nanoparticles. Cancer Lett. 2006; 239(1): 129-135.

16. Buzea C, Pacheco II, Robbie K. Nanomaterials and nanoparticles:sources and toxicity. Biointerphases 2007; 2(4): 17-71.

17. Fischer $\mathrm{HC}$ and Chan WC. Nanotoxicity: the growing need for in vivo study. Curr Opin Biotechnol. 2007; 18(6): 565-571.

18. Sonavane G, Tomada K, Makino K. Biodistribution of colloidal gold nanoparticles after intravenous administration: effect of particle size. Colloids Surf B Biointerfaces. 2008; 66(2): 274-280.

19. Lasagna-Reeves C, Gonzalez-Romero D, Barria MA, Olmedo I, Clos A, Sadagopa Ramanujam VM, Urayama A, Vergara L, Kogan MJ, Soto C. Bioaccumulation and toxicity of gold nanoparticles after repeated administration in mice. Biochem Biophys Res Commun. 2010 ;393(4): 649-655.

20. Heydrnejad MS and Samani RJ. Sex Differential Influence of Acute Orally-administered Silver nanoparticles (Ag-NPs) on Some Biochemical Parameters in Kidney of Mice Mus musculus. J Nanomed Nanotechnol 2016; 7(3): 1000382.

21. Kim WY, Kim J, Park JD, Ryu HY, Yu IJ. 
Histological study of gender differences in accumulation of silver nanoparticles in kidneys of Fischer 344 rats. J Toxicol Environ Health A. 2009;72(21-22) : 1279-1284.

22. Turkevich J, Stevenson PC, Hillier J. A study of the nucleation and growth processes in depends the synthesis of colloidal gold. Discuss Faraday Soc., 1951; 11: 55-75.

23. Zabetakis K, Ghann WE, Kumar S, Daniel MC. Effect of high gold nanoparticles prepared by an extended Turkevich- Frens method. Gold Bull, 2012; 45(4): 203-211.

24. Gaertner, D.J., Hallman, T.M., Hankenson, F.C., Batchelder, M.A. Anesthesia and Analgesia for Laboratory rodents In: Fish RE, Danneman PJ, Brown m, Karas AZ editors Anesthesia and Analgesia in Laboratory Animals, 2nd edition. London (UK) Academic Press, 2008; pp 239-297.

25. Bancroft J.D., Layton C. (2012) The Hematoxylins and Eosin, Ch:10 and Connective and mesenchymal tissues with their stains, Ch:11. In: Theory and Practice of histological techniques, 7th edn, pp.173-214 (eds S.K. Suvarna, C. Layton, J.D. Bancroft), London: Churchill Livingstone. ISBN-13: 780702042263.

26. Ramos-Vara, J.A., Kiupel, M., Baszler, T., Bliven, L., Brodersen, B., Chelack, B., West, K., Czub, S., Del Piero, F., Dial, S., Ehrhart, E.J., Graham, T., Manning, L., Paulsen, D., Valli, V.E.,. Suggested guidelines for immunohistochemical techniques in veterinary diagnostic laboratories. J. Vet. Diagn. Invest. 2008; 20, 393-413.

27. Bozzola JJ and Russell LD. Electron microscopy: principles and techniques for biologists, second edition, Boston, Jones and Bartlett Publishers 1999; pp 100-124

28. Dawson-Saunders, B. and Trapp, R.,. Basic and clinical biostatistics, third edition, Lange Medical Book/ McGraw-Hill, Medical Publishing Division. 2001; pp 161-218.

29. Gupta S, Huda S, Kilpatrick PK, Velev OD. Characterization and optimization of gold nanoparticle-based silverenhanced immunoassays. Anal Chem. 2007; 79(10):3810-3820.

30. Adeyemi OS and Sulaiman FA. Evaluation of metal nanoparticles for drug delivery systems. J Biomed Res. 2015 ; 29(2):145-149.
31. Gerber A, Bundschuh M, Klingelhofer D, Groneberg DA. Gold nanoparticles: Recent aspects for human toxicology. J Occup Med Toxicol. 2013; 8(1): 32.

32. Yah, CS. The toxicity of gold nanoparticles in relation to their physicochemical properties. Biomed. Res. 2013; 24(3): 400-413.

33. Choi SJ, Lee JK, Jeong J, Choy JH. Toxicity evaluation of inorganic nanoparticles: Considerations and challenges. Mol. Cell. Toxicol. 2013; 9(3): 205-210.

34. Dykman L and Khlebtsov N. Gold nanoparticles in biomedical applications: Recent advances and perspectives. Chem. Soc. Rev. 2012; 41: 2256-2282.

35. Chen YS, Hung YC, Liau I, Huang GS. Assessment of the in vivo toxicity of gold nanoparticles. Nanoscale Res Lett. 2009; 4(8): 858-864.

36. Choi CHJ, Zuckerman JE, Webster P, Davis ME. Targeting kidney mesangium by nanoparticles of defined size. Proc Natl Acad Sci U S A. 2011; 108(16): 6656-6661.

37. Abdelhalim MAK and Jarrar BM. The appearance of renal cells cytoplasmic degeneration and nuclear destruction might be an indication of GNPs toxicity. Lipids in Health and Disease 2011; 10: 147.

38. Sun J, Zhang Q, Wang Z, Yan B. Effects of Nanotoxicity on Female Reproductivity and Fetal Development in Animal Models. Int J Mol Sci. 2013; 14(5): 9319-9337.

39. Abdelhalim MAK and Moussa SAA. The gold nanoparticle size and exposure duration effect on the liver and kidney function of rats: In vivo. Saudi J Biol Sci. 2013; 20(2): 177-181.

40. Schrand AM, Rahman MF, Hussain SM, Schlager JJ, David A, Smith DA, Syed AF. Metal-based nanoparticles and their toxicity assessment. Wiley Interdiscip Rev Nanomed. Nanobiotechnol. 2010; 2(5): 544-568.

41. Del Monte U. Swelling of hepatocytes injured by oxidative stress suggests pathological changes related to macromolecular crowding. Med Hypotheses. 2005; 64(4): 818-825.

42. Kumar V, Abbas A, Aster J, Fausto N. Robbins and Cotran Pathologic Basis of Disease. 2007; 8th 
edition, Saunders-Elsevier.pp 20-28.

43. Pandey G, Srivastava DN, Madhuri S. A standard hepatotoxic model produced by paracetamol in rat. Toxicol. Int. 2008; 15(1): 69-70.

44. Tsuboi N, Kawamura T, Ishii T, Utsunomiya $\mathrm{Y}$ and Hosoya T. Changes in the glomerular density and size in serial renal biopsies during the progression of IgA nephropathyNephrol. Dial. Transplant. 2009; 24 (3): 892-899.

45. Kataoka H, Ohara M, Honda K, Mochizuki $\mathrm{T}$ and Nitta K. Maximal glomerular diameter as a 10-year prognostic indicator for $\operatorname{IgA}$ nephropathy. Nephrol. Dial. Transplant. 2011; 26(12): 3937-3943.

46. Terentyuk G, Maslyyakova G, Suleymanova L, Kogan B, Khlebtsov B, Akchurin G, Makisimova I, Shantrokha A, Tuchin V. Tracking gold nanoparticles in the body. J Biomedical Optics. 2009; 14: 19-16.

47. Inumaru $\mathrm{J}$, Tanihar $\mathrm{H}$, Umezawa $\mathrm{k}$, Niwa $\mathrm{S}$, Suzuki Y, Nakumura S, Ishimoto T, Takahashi E, Nagano O, Saya H: Molecular mechanisms regulating dissociation of cell-cell junction of epithelial cells by oxidative stress. Genes Cells. 2009; 14 (6): 703-716.

48. Johar D, Roth JC, Bay GH, Walker JN, Kroczak $\mathrm{TJ}$, Los M. Inflammatory response, reactive oxygen species, programmed (necrotic-like and apoptotic) cell death and cancer. Rocz Akad Med Bialymst. 2004;49: 31-39.

49. Elsabahy E and Wooley KL. Cytokines as biomarkers of nanoparticle immunotoxicity Chem Soc Rev. 2013; 42(12): 5552-5576.

50. Yen HJ, Hsu SH, Tsai CL. Cytotoxicity and immunological response of gold and silver nanoparticles of different sizes. Small. 2009; 5(13): 1553-1561.

51. Jong WHD, Burger MC, Verheijen MA, Geertsma RE. Detection of the presence of gold nanoparticles in organs by transmission electron microscopy. Materials 2010; 3(9): 4681-4694.

52. Choi HS, Liu W, Misra P, Tanaka E, Zimmer JP, Ipe BI, Bawendi MG, Frangioni JV. Renal clearance of quantum dots. Nat biotechnol 2007; 25(10): 1165-1170.

53. Cho WS, Cho M, Jeong J, Choi M, Han BS,
Shin HS, Hong J, Chung BH, Jeong J, Cho MH. Size-dependent tissue kinetics of PEG-coated gold nanoparticles. Toxicol Appl Pharmacol 2010; 245(1): 116-123.

54. Fischer HC, Liu L, Pang KS, Chan WCW. Pharmacokinetics of nanoscale quantum dots: in vivo distribution, sequestration, and clearance in the rat. Adv Funct Mater 2006; 16: 1299-1305.

55. Zhou C, Long M, Qin Y, Sun X, Zheng J. Luminescent gold nanoparticles with efficient renal clearance. Angew Chem Int Ed Engl 2011; 50(14): 3168-3172.

56. Yih TC and Wei TC. Nanomedicine in cancer treatment. Nanomedicine: Nanotechnology. Biology, and Medicine. 2005; 1(2): 191- 192.

57. Sadauskas E, Wallin H, Stoltenberg M, Vogel U, Doering P, Larsen A, Danscher G. Kupffer cells are central in the removal of nanoparticles from the organism. Part Fibre Toxicol. 2007; 4: 10.

58. Geiser M, Rothen-Rutishauser B, Kapp N, Schürch S, Kreyling W, Schulz H, Semmler M,Im Hof V, Heyder J, Gehr P. Ultrafine particles cross cellular membranes by nonphagocytic mechanisms in lungs and in cultured cells. Environmental Health Perspectives 2005; 113(11): 1555-1560.

59. Rothen-Rutishauser BM, Schürch S, Haenni B, Kapp N, Gehr P. Interaction of fine particles and nanoparticles with red blood cells visualized with advanced microscopic techniques. Environ. Sci. Technol 2006; 40(11): 4353-4359.

60. Jong WHD, Hagens WI, Krystek P, Burger MC, Sips AJAM, Geertsma RE. Particle sizedependent organ distribution of gold nanoparticles after intravenous administration. Biomaterials 2008; 29(12): 1912-1919.

61. Cho WS, Cho M, Jeong J, Choi M, Cho HY, Han BS, Kim SH, Kim HO, Lim YT, Chung BH, Jeong J. Acute toxicity and pharmacokinetics of $13 \mathrm{~nm}$ sized PEG-coated gold nanoparticles. Toxicol Appl Pharmacol. 2009; 236(1): 16-24.

62. Cho WS, Kim S, Han BS, Son WC, Jeong J. Comparison of gene expression profiles in mice liver following intravenous injection of 4 and 100 nm-sized PEG-coated gold nanoparticles. Toxicol Lett. 2009; 191(1): 96-102.

63. Nghiem THL, Nguyen TT, Fort E, Nguyen TP, Nhung Hoang TM, Nguyen TQ. Capping and 
in vivo toxicity studies of gold nanoparticles. Adv Nat Sci: Nanosci Nanotechnol. 2012; 3(1): 015002 .

64. Brandenberger C, Muhlfeld C, Ali Z, Lenz AG, Schmid O, Parak WJ, Gehr P, RothenRutishauser B. Quantitative evaluation of cellular uptake and trafficking of plain and polyethylene glycol-coated gold nanoparticles. Small. 2010; 6(15): 1669-1678.

65. Shenoy D, Fu W, Li J, Crasto C, Jones G, DiMarzio C, Sridhar S, Amiji M. Surface functionalization of gold nanoparticles using hetero-bifunctional poly(ethylene glycol) spacer for intracellular tracking and delivery. Int $\mathrm{J}$ Nanomedicine. 2006; 1(1): 51-57.

66. Chen J, Wang H, Long $\mathrm{W}$, Shen $\mathrm{X}$, Wu D, Song S, Sun Y, Liu P, Fan S, Fan F, Zhang
$X$. Sex differences in the toxicity of polyethylene glycol-coated gold nanoparticles in mice.Int $\mathbf{J}$ Nanomedicine. 2013; 8: 2409-2419.

67. Sabella S, Carney RP, Brunetti V, Malvindi MA, Juffali NA Vecchio G, Janes SM, Bakr OM, Cingolani R, Stellacci F, Pompa PP. A general mechanism for intracellular toxicity of metal-containing nanoparticles. Nanoscale, 2014; 6(12): 7052-7061.

68. Barnard PJ and Berners-Price SJ. Targeting the mitochondrial cell death pathway with gold compounds. Coord. Chem. Rev., 2007; 251: 1889-1902.

69. Tait SWG and Green DR. Mitochondria and cell death: outer membrane permeabilization and beyond. Nat. Rev. Mol. Cell Biol., 2010; 11(9): 621-632. 
الملغص العربى

\title{
التقييم الهستولوجى و الهستوكيميائي المناعي للتأثثر المعتمد على الجرعة لجسيمات الذهب النانوية على القشرة الكلوية لإناث الجرذان البير البيضاء على الجبالغة
}

\author{
ولاء محمد علوان16 أيه محمد حسن رجب؛20ممد حسن رجب3

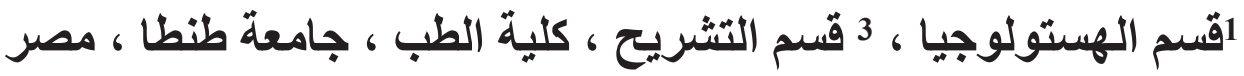 \\ 2 قسم الصحة الانجابية وتنظيم الأسرة ، المركز القومى للبحوث ، الجيزة ، مصر ،
}

المقدمة: تؤدى تطبيقات جسيمات الذهب النانوية فى الحياة الحديثة الى اطلاق سر اح هذه الجسيمات الى البيئة، مما يمثل خطر ا محتملا للصحة البشرية.

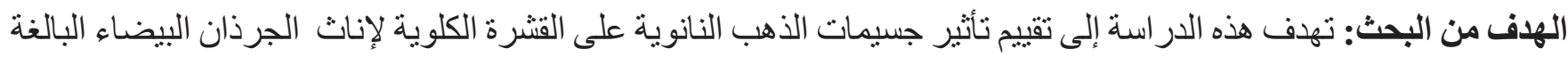

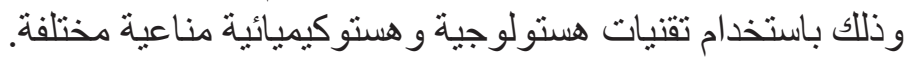

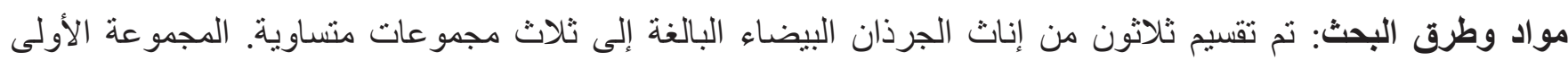

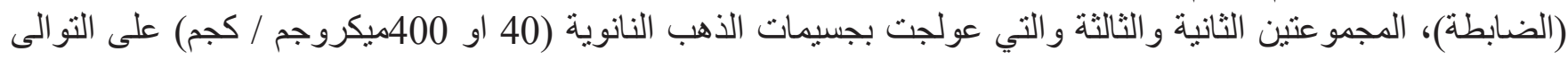
يوميا لمدة 14 يوم. تم تجهيز عينات للفحص بالمجهر الضوئى و المجهر الإلكتروني. كما تم عمل صبغات هستوكيميائية مناعية

بإستخدام أجسام ضد

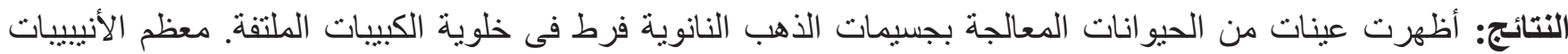

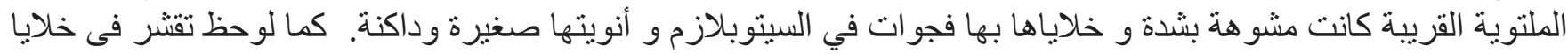

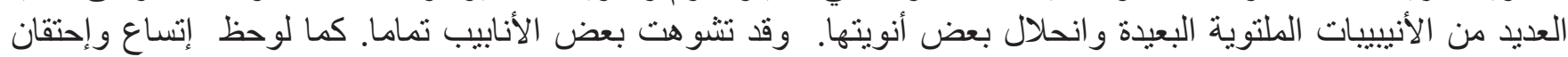

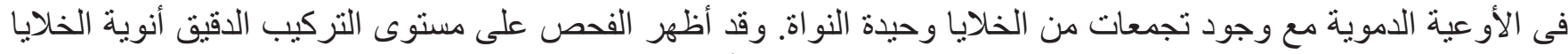

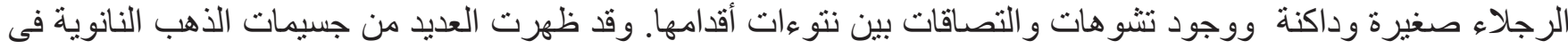

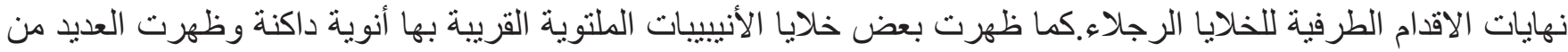

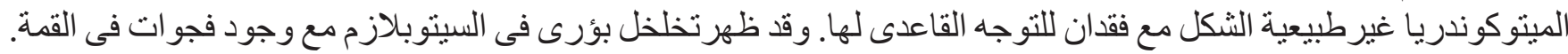

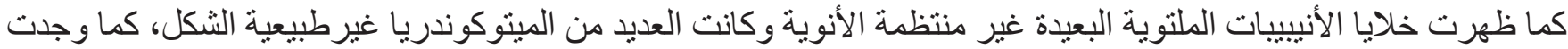

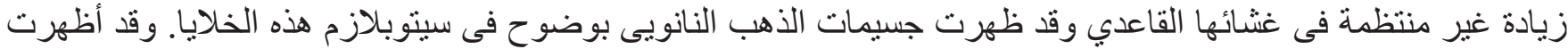

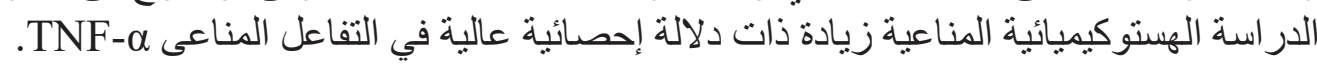
الإستنتاج: : تجسيمات الذهب النانوية تسببت فى حدوث تغير ات نركيبية معتمدة على الجرعة ودراتية ودرات مختلفة من الالتهاب فى القشرة الكلوية. 